\title{
Становление концепций печати в Западной Европе и США
}

(краткий обзор)

Григорий Прутцков

В статье рассматривается период становления концепций печати в Западной Европе и Соединенных Штатах Америки, предшествовавших современным национальным медиасистемам. Автор анализирует сущностные характеристики английской, американской и французской концепций печати, которые формировались в Западной Европе и Соединенных Штатах Америки на протяжении XVII-XIX вв.

Ключевые слова: концепции печати, пресса, журналистика, СМИ, медиа.

DOI: 10.30547/mediaalmanah.5.2020.123128
() Прутцков Григорий Владимирович кандидат филологических наук, доцент кафедры зарубежной журналистики и литературы факультета журналистики МГУ имени М.В. Ломоносова (г. Москва, Россия), pruttskov@gmail.com

\section{Введение}

Концепция печати - термин, впервые появившийся в книге «Четыре теории прессы» Ф. Сиберта, У. Шрамма и Т. Питерсона (1956). Это была первая попытка систематизировать медиасистемы разных стран. Исходя из того, "...как СМИ могли бы функционировать <...> согласно определенным критериям, характерным для конкретного общества нормам и ценностям», ученые выделили четыре теории (концепции) прессы: авторитарная, либертарианская, социальная и советская коммунистическая. В России данный термин впервые был введен профессором Я.Н. Засурским (1998).

Сегодня, когда в академических кругах активно ведутся дискуссии о многообразии национальных медиасистем, отечественные (Вартанова, 2019; Шкондин, 2015) и зарубежные (Curran, Seaton, 1997; Hallin, Mancini, 2004; McQuail, 2005; Hardy, 2008, 2012) исследователи предлагают диверсифицированные подходы к их классификации, пытаясь более точно и полно определить само понятие «медиасистема», особенно важна актуализация исторического опыта. Появляется необходимость обратиться к истокам - периоду, когда в Западной Европе и Соединенных Штатах Америки (на протяжении XVII-XIX вв.) формировались концепции прессы, предшествовавшие современным национальным 
медиасистемам, - английская, американская, французская.

\section{Предпосылки появления концепций печати}

Изобретение книгопечатания Иоганном Гуттенбергом в середине XV в. привело к быстрому распространению печати. Однако от появления книгопечатания до создания первой газеты в Европе прошло полтора века. K началу XVII в. были подготовлены важнейшие условия создания периодической печати: печатный станок, система распространения печатного слова, наличие потенциальных читателей из числа грамотных жителей городов.

Датой появления первой печатной газеты в Европе считается 1605 г. В течение первой половины XVIIв. газеты выходили в большинстве европейских стран. Они носили целиком частный характер. Никакой типологии прессы тогда не существовало, поэтому одни и те же периодические издания в разных источниках называют то газетами, то журналами. Практически во всех европейских странах была в то время достаточно жесткая цензура, поэтому нередко первый номер газеты становился и последним.

В начале 1630 гг. повляется пресса, представляющая интересы власти. Кардинал Ришелье, став в 1624 г. главой правительства Франции, едва ли не первым в Европе понял, какую роль может сыграть печать в формировании общественного мнения, и стремился использовать зарождающуюся журналистику для достижения своих политических целей. Ришелье задумал издание государственной газеты, которая помогала бы управлять государством и была бы мощным рупором авторитарной власти.

Именно таким периодическим изданием стала La Gazette (Alber, 1970: 8-11), первый номер которой вышел в Париже при дворе Людовика XIII 30 мая 1631 г. La Ga-zette стала первым общенациональным периодическим изданием. С ее появлением во
Франции постепенно сложилась авторитарная журналистика. Для нее характерны следующие основные особенности:

- пресса является рупором власти, через нее не только сообщаются новости, но и рассылаются директивы на места;

- существует жесткая предварительная цензура;

- действует система лицензирования прессы;

- правдивая информация часто приносится в жертву интересам власти;

- пресса имеет вертикальную структуру. Зародившись во Франции в середине XVII в., авторитарная журналистика в разное время и с разной продолжительностью существовала почти во всех странах мира. Ей на смену пришла журналистика, основанная на демократических принципах.

\section{Английская концепция печати}

Уже в XVII в. стало очевидно, что любые войны, революции, общественные нестроения провоцировали повышенный интерес населения к информации, к печатному и устному слову. Данная закономерность существует и сегодня. Революционные события 1640-1660 гг. на Британских островах резко повысили популярность и значение журналистики.

В ноябре 1644 г. Джон Мильтон опубликовал памфлет «О свободе печати. Речь к английскому парламенту (Ареопагитика)» (Засурский, Вартанова (ред.), 2001: 7-64). Идеи Мильтона легли в основу английской концепции печати (ее также называют мильтоновской, или либертарианской, от англ. liberty - свобода), разработанной в Билле о правах в 1689 г., - документе, который до сих пор играет роль английской конституции и закона о печати. Для журналистов был самым важным девятый параграф: «Свобода слова, прений и всего, что происходит в парламенте, не может быть поводом для преследования, быть предметом рассмотрения в суде и нигде, кроме парламента». 
Согласно первой в мире демократической концепции журналистики, только парламент может регулировать работу прессы. Кроме того:

- отвергается контроль со стороны государства и церкви;

- провозглашается экономическая свобода (т.е. прессу могут издавать все, у кого есть идеи и деньги);

- решающий фактор - не политический, а экономический;

- впервые появляется понятие «свобода слова».

Свобода печати привела к появлению новых газет и журналов. Так, только с 1688 по 1692 г. в Англии возникли 26 периодических изданий. Но, несмотря на рост числа новых периодических изданий, далеко не сразу английская печать смогла воспользоваться реальными плодами декларированной в Билле о правах свободы. Парламент еще более чем полтора века пытался сдерживать рост и влияние прессы экономическими методами, вводя различные налоги (например, штемпельный налог, налог на бумагу, объявления), а также законы о клевете, о позорном столбе. Например, сущность штемпельного налога состояла в том, что на каждую страницу газеты ставился штемпель, и сумма платежа зависела от количества страниц издания. Поскольку подавляющее большинство газет в то время издавались форматом A-5 (современный тетрадный лист), штемпельный налог лег серьезным бременем на журналистику, едва освободившуюся от притеснений предварительной цензуры.

\section{Американская концепция печати}

Печать Соединенных Штатов Америки формировалась в условиях отсутствия предварительной цензуры и в целом носила местный характер. В силу своей удаленности от центров цивилизации того времени и подражательного характера прессы она не оказывала практически никакого влияния на мировую журналистику.
В основу американской концепции печати легла Первая поправка к Конституции США 1787 г. - одна из десяти поправок, принятых 21 декабря 1791 г., так называемый американский Билль о правах (Яковлев (ред.), 2000: 25). Первая поправка гласит: «Конгресс не будет издавать законов, ограничивающих свободу слова, или печати, или права народа мирно собираться» (Прутцков, 2010: 410).

Для американской концепции печати характерно следующее:

- полное отделение печати от государства, печать и государство независимы друг от друга;

- государство не может иметь свою прессу; впервые законодательно утверждается свобода печати;

- концепция рассчитана на индивидуальную свободу.

Защищенность от контроля со стороны федерального правительства, продекларированная в Первой поправке, означала на практике, что любой человек, вне зависимости от его финансового положения, политических и религиозных убеждений, мог публиковать что угодно. Журналистика, таким образом, становилась частным предприятием, никак не зависящим от государства.

Права и свободы, приобретенные американской печатью в конце XVIII в., начали воплощаться в жизнь без серьезных препятствий со стороны государства. Развитие американской концепции печати привело к процветанию американской журналистики в последующие десятилетия.

K середине XIX в. сложились основные особенности американской журналистики. Главная из них заключалась в местном характере прессы: газеты и журналы, как правило, не выходили за пределы городов и штатов, где они издавались. Соответственно, отсутствовали или оставались неразвитыми общенациональные периодические издания. Во многом такое положение вещей было связано с особенностями 
восприятия читателями рекламы в прессе. Американцы предпочитали не имиджевую, абстрактную, но адресную рекламу: где, когда, в каком магазине, с какими скидками можно приобрести тот или иной товар. Публиковать такую рекламу можно исключительно в местных периодических изданиях (доля рекламы в них занимала до $75 \%$ объема).

Подобным отношением к рекламе объясняется еще одна особенность американской журналистики XIX в.: преобладание вечерней прессы над утренней. Рекламные объявления удобнее всего было читать вечером, когда американцы приходили домой с работы. Реклама в утренних газетах, которая версталась накануне, к вечеру часто устаревала.

\section{Французская концепция печати}

Французская концепция печати была во многом предвосхищена деятельностью просветителей XVIII в. Многие идеи Вольтера, Руссо, Дидро, Монтескье легли в основу Декларации прав человека и гражданина первого документа, который лег в основу французской концепции печати. Декларацию приняло Национальное учредительное собрание через месяц после начала Великой французской революции - 24 августа 1789 г. Ее одиннадцатая статья гласит: «Свободное выражение мыслей и мнений является одним из драгоценнейших прав человека. Каждый гражданин вправе, следовательно, свободно говорить, писать и печатать, отвечая за злоупотребления этой свободой лишь в случаях, предусмотренных законами» (Новомбергский, 2001: 219).

Так начала складываться французская концепция свободы печати. Ее становление проходило болезненно: почти целое столетие после принятия Декларации шла борьба за реальное воплощение в жизнь ее принципов. Свобода печати, провозглашенная в 1789 г. и подтвержденная декретом законодательного собрания в 1791 г., была отменена в 1800 г. Наполеоном.
Впоследствии свобода печати вновь неодно кратно декларировалась и отменялась. 29 июля 1881 г. был принят Закон о печати - один из наиболее ярких документов в истории мировых медиа. Он продолжал и развивал идеи 11-й статьи Декларации прав человека и гражданина 1789 г. Закон действует уже около 140 лет, а возникающие с тех пор вопросы и проблемы деятельности средств массовой информации решались и решаются в дополнительных законах, опирающихся на этот фундаментальный законодательный акт. Закон 1881 г. стал образцом для соответствующих законодательств многих других стран, в том числе для России.

Отличительные черты французской концепции свободы печати:

- бо́льшая, в сравнении с английской и тем более американской концепцией, роль государства в журналистике;

- журналистика регламентируется законодательством;

- впервые появляется выражение «права человека».

Закон навсегда отменял цензуру, предварительное разрешение, залог, гербовый сбор и многие другие существовавшие ограничения для прессы. Отменялись также наказания за так называемые преступления мнений: выступления против конституции, всеобщего избирательного права, частной собственности, культов, семьи. Отныне для издания газеты достаточно было лишь направить по почте письмо прокурору Парижа с указанием названия предполагаемой газеты, имени, адреса издателя и владельца. Однако для регулярного издания прессы требовалась обладать огромными деньгами: не менее 500 тыс. франков.

Ограничения для журналистов и журналистики были зафиксированы в восьми пунктах. Прессе запрещалось: подстрекательство к преступлениям и правонарушениям, прямые или косвенные призывы к бунту и мятежу, тяжкое оскорбление президента, правительства и парламента, а также дипломатов и руководителей 
других государств, публикация ложных сведений, нарушающих порядок и общественное спокойствие, тяжкое оскорбление нравственности, клевета. Виновность газеты мог устанавливать лишь суд присяжных.

\section{Предпосылки трансформации концепций печати в XIX в.}

B XIX в. решающее влияние на развитие мировой журналистики оказало совершенствование техники и технологии издательского дела. Использование новых достижений привело не только к появлению новой типологической характеристики прессы (качественная и массовая), но и к изменению внутреннего и внешнего облика газеты. Постепенно начала формироваться и система прессы в сегодняшнем ее понимании.

Научно-технический прогресс привел к резкому увеличению потока информации. Крупные сдвиги наметились и в экономике газеты. Таким образом, удовлетворить потребности такой большой категории читателей стало и возможно, и выгодно. Кроме того, начиная с 1830-1840 гг. пресса стала играть активную роль в политической борьбе, поэтому различные политические силы - от короля и правительства до оппозиции - были заинтересованы в создании дешевой газеты, доступной не только элите, но и простым людям.

К концу XIX в. мир обогатился изобретениями, которые привели в первой половине XX столетия к возникновению новых средств массовой информации. Уже в середине XIX столетия в разных странах Европы и в США начались разработки технологий передачи на расстояние неподвижных изображений, непосредственно предшествовавших изобретению телевидения. В 1895 г. русский ученый Александр Степанович Попов на заседании Русского физико-химического общества продемонстрировал изобретенный им прибор "грозоотметчик», предназначенный для регистрации электромагнитных волн.
Это был первый в мире радиоприемник аппарат беспроводной телеграфии (фактически радио стало средством массовой информации к началу 1920 гг.). В 1895 г. французский изобретатель Луи Люмьер изобрел и запатентовал киноаппарат для съемки и воспроизведения кинофильмов - «движущихся фотоснимков», которые он сам назвал "кинематограф», а также совместно с братом Огюстом Люмьером снял первые в истории документальные фильмы.

Таким образом, политическое развитие в странах Запада привело к появлению законодательной базы, способствовавшей развитию печати. Техническая и технологическая революция в издательском деле сделала печать оперативной и доступной. Во многом благодаря этим факторам к концу XIX в. в мире окончательно сформировались и активно действовали английская, американская и французская концепции печати.

\section{Заключение}

Западная журналистика, сформировавшаяся в рамках английской, американской и французской концепций печати, на протяжении веков претерпевала существенные изменения. Можно выделить ряд факторов, существенно влияющих на развитие и становление СМИ, к числу которых относятся:

- Государственная политика в области средств массовой информации (в особенности государственная цензура). Разная степень свободы в государствах, налоги, которыми облагались издания, степень вмешательства государства в направленность СМИ и прочие факторы, отличавшиеся в разных странах, привели к формированию различных концепций печати. (Отметим, что данный фактор является весьма значимым и актуальным до сих пор. Как подчеркивает Е.Л. Вартанова (2019: 87): «Журналистика и СМИ по-прежнему остаются в тесной связи с национальной политической и экономической системой своих стран, 
напрямую зависят от особенностей государственного устройства и культурного контекста, в котором они присутствуют».)

- Научно-технический прогресс. Скорость, с которой люди стали узнавать о новостях, а также появление разнообразия в форме подачи материала приводят к существенной трансформации концепций печати и во многом влияют на их становление в медиасистемы.

- Крупные международные события. Революции, военные конфликты наложили свой отпечаток на СМИ и, как следствие, задавали им новый вектор развития.
Исторический опыт функционирования западноевропейской и американской прессы показывает, что некоторые особенности современных национальных медиасистем были сформированы еще задолго до становления и медиасистемы как структурного компонента современных обществ, и появления школы изучения национальных медиасистем, возникшей только во второй половине XX века. Современные медиасистемы сложились и развиваются в рамках иных концепций, поэтому необходимо продолжать соответствующие теоретические исследования.

\section{Библиография}

Вартанова Е.Л. Теория медиа: отечественный дискурс. М.: Изд-во Моск. ун-та, 2019. Засурский Я.Н. Предисловие редактора // Сиберт Ф.С., Шрамм У., Питерсон Т. Четыре теории прессы. М.: Нац. инт-т прессы; Вагриус, 1998.

Мильтон Д. О свободе печати (Ареопагитика) // История печати: Антология / под ред. Я.Н. Засурского, Е.Л. Вартановой. М.: Аспект Пресс, 2001. С. 7-64.

Новомбергский Н.Я. Освобождение печати во Франции, Германии, Англии и России. Лекции, читанные в Русской Высшей Школе общественных наук в Париже // История печати: Антология. Т. 1 [Сер.: Классика журналистики]. М.: Аспект Пресс, 2001. Режим доступа: http://evartist.narod.ru/text2/30.htm\#\%D0\%B7_03

Прутцков Г.В. Введение в мировую журналистику. От Античности до конца XVIII века. М.: Аспект Пресс, 2010.

Федералист. Политические эссе А. Гамильтона, Дж. Мэдисона и Дж. Джея / под ред. Н.Н. Яковлева. М.: Весь Мир, 2000.

Шкондин М.В. Информационный потенциал общества и концепты целостности медиасистемы // Вопросы теории и практики журналистики. 2015. Т.4. № 4. С. 335-348.

Albert P. (1970) Histoire de la Presse. Paris: Presse Universitaire de France, reimpression de la 10-eme ed., ss. 8-11.

Curran J., Seaton J. (1997) Power without Responsibility. The Press and Broadcasting in Britain. $5^{\text {th }}$ ed. London; NY: Routledge.

Hallin D.C., Mancini P. (2004) Comparing Media Systems: Three Models of Media and Politics (Communication, Society and Politics). Cambridge: Cambridge University Press.

Hardy J. (2008) Western Media Systems. New York: Routledge.

Hardy J. (2012) Comparing Media Systems. In: Esser F., Hanitzsch T. (eds.) Handbook of Comparative Communication Research. London: Routledge, pp. 185-206.

McQuail D. (2005) McQuail's Mass Communication Theory. $5^{\text {th }}$ ed. London: Sage.

Siebert F., Schramm W., Peterson T. (1956) Four Theories of the Press: The Authoritarian, Libertarian, Social Responsibility, and Soviet Communist Concepts of What the Press Should be and Do. University of Illinois Press. 